\title{
PRODUKSI TANAMAN SORGUM (Sorghum bicolor (L.) Moench) VARIETAS LOKAL ROTE SEBAGAI HIJAUAN PAKAN RUMINANSIA PADA UMUR PANEN DAN DOSIS PUPUK UREA YANG BERBEDA
}

\section{PRODUCTION OF SORGHUM PLANT (Sorghum bicolor (L.) Moench) OF ROTE LOCAL VARIETY AS FORAGE FOR RUMINANT FEED AT DIFFERENT OF HARVEST TIME AND UREA LEVEL}

\author{
Bernadete Barek Koten $^{1 *}$, R. Djoko Soetrisno ${ }^{2}$, Nono Ngadiyono $^{2}$, dan Bambang Suwignyo ${ }^{2}$ \\ ${ }^{1}$ Jurusan Peternakan, Politeknik Pertanian Negeri Kupang, Jl. Adisucipto Penfui Kupang, NTT \\ ${ }^{2}$ Fakultas Peternakan, Universitas Gadjah Mada, Jl. Fauna No. 3, Bulaksumur, Yogyakarta, 55281
}

\section{INTISARI}

Penelitian bertujuan untuk mengevaluasi kemampuan produksi tanaman sorgum varietas lokal Rote sebagai pakan ternak ruminansia pada umur panen dan dosis urea yang berbeda. Penelitian dilaksanakan di rumah kaca Laboratorium Hijauan Makanan Ternak dan Pastura Fakultas Peternakan UGM selama 4 bulan dari tanggal 11 November 2011 hingga 27 Februari 2012. Penelitian ini dirancang dengan Rancangan Acak Lengkap pola faktorial dengan 2 faktor perlakuan yaitu umur panen (UP) sebagai faktor pertama (UP1= 50 hari, UP2 $=70$ hari, dan UP3 $=90$ hari) dan dosis pupuk urea (P0 = tanpa urea sebagai kontrol, $\mathrm{P} 1=50 \mathrm{~kg} / \mathrm{ha}$, dan $\mathrm{P} 2=100 \mathrm{~kg} / \mathrm{ha})$ sebagai faktor kedua. Kombinasi perlakuan ini diulang 4 kali. Variabel yang diamati adalah produksi bahan kering (BK), bahan organik (BO), dan protein kasar (PK) (g/polibag). Hasil penelitian menunjukkan bahwa produksi BK tertinggi terdapat pada perlakuan UP3P2 (107,27 g/polibag) dan berbeda sangat nyata $(\mathrm{P} \leq 0,01)$ dengan UP3P1, UP3P0, UP2P2, UP2P1, UP2P0, UP1P2, UP1P1, dan UP1P0. Perlakuan UP3P2 dan UP3P1 menghasilkan produksi BO yang lebih tinggi yaitu 108,07 dan 84,70 g/polibag, dibandingkan dengan UP3P0, UP2P2, UP2P1, dan UP2P0. Produksi BO terendah terdapat pada kombinasi perlakuan UP1P0 (25,60 g/polibag) dan tidak berbeda nyata dengan UP1P2 (32,88 g/polibag) dan UP1P1 (28,70 g/polibag). Produksi PK tertinggi terdapat pada perlakuan UP2P2 (5,57 g/polibag) dan tidak berbeda nyata dengan UP3P2 (5,14 g/polibag) dan UP1P2 (5,03 g/polibag). Produksi PK berbeda dengan UP3P1, UP2P1 dan UP1P1. Produksi PK juga berbeda dengan UP1P0 dan UP2P0. Perlakuan UP3P0 merupakan kombinasi perlakuan yang menghasilkan produksi PK terendah yaitu 2,22 g/polibag. Disimpulkan bahwa tanaman sorgum yang dipanen pada umur 90 hari dengan dosis pupuk urea $100 \mathrm{~kg} / \mathrm{ha}$, menghasilkan hijauan terbaik sebagai pakan ruminansia.

(Kata kunci: Sorgum, Umur panen, Dosis urea, Produksi bahan kering, Produksi protein kasar)

\section{ABSTRACT}

The aim of this experiment was to evaluate the production of sorghum plant (Sorghum bicolor (L.) Moench) of Rote local variety as forage for ruminant feed at different combination of harvest time and urea level. The experiment conducted for 4 months (November 11 - February 27, 2012) at the green house of forage and pasture laboratory, Faculty of Animal Science Gadjah Mada University, and in 2 treatment factors with 4 replications. The first factor was various harvesting time consisting of 50 (UP1), 70 (UP2) and 90 (UP3) days and the second factor was various level of urea consisting of $0(P 0), 50(P 1)$ and $100(P 2) \mathrm{kg} / \mathrm{ha}$. Parameters measured were dry matter, organic matter, and crude protein production. The result showed that the highest dry matter production was at UP3P2 (107.27 g/polybag), and significantly different $(P \leq 0,01)$ with UP3P1, UP3P0, UP2P2, UP2P1, UP2P0, UP1P2, UP1P1 and the lowest value at UP1P0 (25.34 g/polybag). The highest organic matter production were at UP3P2 (108.07) and UP3P1 (84.70 g/polybag) and significantly different with UP3P0, UP2P2, UP2P1, UP2P0, and the lowest was at UP1P0 (25.60 g/polybag) not different with UP1P2 (32.88) and UP1P1 (28.70 g/polybag). The highest crude protein production was at UP2P2 (5.57 g/polybag) not different $(P \geq 0.05)$ with UP3P2 (5.14) and UP1P2 (5.03 g/polybag), but significantly different $(P \leq 0.01)$ with UP1P0 dan UP2P0. The lowest crude protein production was at UP3P0 (2.22 g/polybag). It could be concluded that sorghum plant harvested at 90 days with level of urea $100 \mathrm{~kg} / \mathrm{ha}$ had the highest productions of dry matter, organic matter and crude protein.

(Key words: Sorghum, Harvesting time, Level of urea, Dry matter production, Crude protein production)

\footnotetext{
* Korespondensi (corresponding author):

Telp. +62 85292869170

E-mail: bernadete_koten@yahoo.com
} 


\section{Pendahuluan}

Hijauan merupakan sumber pakan utama bagi ternak ruminansia. Produktivitas ternak ruminansia sangat ditentukan oleh ketersediaan pakan yang berkualitas dan berkesinambungan. Kondisi ini masih merupakan kendala di Nusa Tenggara Timur (NTT) terutama pada musim kemarau. Sorgum (Sorghum bicolor (L.) Moench) merupakan tanaman serealia yang potensial untuk dibudidayakan dan dikembangkan sebagai pakan ternak ruminansia, khususnya pada daerah-daerah marginal dan kering di Indonesia. Sorgum tumbuh tegak dan mempunyai daya adaptasi agroekologi yang luas, tahan terhadap kekeringan, produksi tinggi, membutuhkan input lebih sedikit serta lebih tahan terhadap hama dan penyakit dibanding tanaman pangan lain. Sorgum memiliki kandungan nutrisi yang tinggi, $332 \mathrm{kal}$ kalori dan $11,0 \mathrm{~g}$ protein $/ 100 \mathrm{~g}$ biji pada biji, dan bagian vegetatifnya $12,8 \%$ protein kasar, sehingga dapat dibudidayakan secara intensif sebagai sumber pakan hijauan bagi ternak ruminansia terutama pada musim kemarau (OISAT, 2011). Sorgum lokal varietas Rote adalah salah satu jenis sorgum yang dibudidayakan oleh masyarakat NTT. Potensi yang ada pada sorgum varietas lokal ini, dapat dikembangkan untuk menjadi sumber pakan berkualitas terutama pada musim kemarau.

Tingkat kedewasaan tanaman merupakan faktor terpenting yang mempengaruhi produksi dan nilai nutrisi hijauan (Mc Donald et al., 2002). Selama masa vegetatif, produksi tanaman akan lebih banyak dari kebutuhan. Kelebihan hasil asimilasi ini akan disimpan pada bagian vegetatif sebagai senyawa cadangan. Senyawa cadangan tersebut sebagian besar tersusun dari karbohidrat tetapi sering juga mengandung cukup banyak lipid dan protein. Dengan meningkatnya umur tanaman, total karbohidrat non struktural pada tanaman rumput akan semakin tinggi (Budiman et al., 2011). Akan tetapi pada fase lebih lanjut saat tanaman berbuah, senyawa cadangan tersebut akan ditranslokasikan ke perkembangan biji (Gardner et al., 2008). Huston dan Pinchak (2008) menjelaskan lebih lanjut bahwa dengan meningkatnya umur tanaman terutama saat memasuki fase generatif maka rasio batang dan daun meningkat yang mengakibatkan nilai makanan berkurang. Tanaman akan berkurang kandungan protein, mineral, dan karbohidrat mudah larut dengan meningkatnya umur tanaman sedangkan kandungan serat kasar dan ligninnya bertambah karena secara umum daun mengandung protein kasar yang lebih tinggi. Umur panen merupakan aspek yang erat hubungannya dengan fase pertumbuhan tanaman, yang mempunyai relevansi yang akurat dengan produksi dan nilai nutrien dan kecernaan. Penentuan umur panen yang tepat sangat diperlukan untuk menjamin tingginya produksi tanaman dengan nilai nutrisi yang memadai sebagai pakan ternak.

Kebutuhan tanaman pakan akan nitrogen $(\mathrm{N})$ sangat tinggi terutama dari kelompok rumputrumputan termasuk sorgum. Nitrogen ini berguna untuk meningkatkan pertumbuhan, produksi dan kualitas hijauan tanaman serta dapat memperlambat masaknya biji (memperpanjang masa vegetatif). Kondisi ini menyebabkan akumulasi hasil fotosintesis dalam tanaman dapat berlangsung lebih lama sehingga meningkatkan produktivitas tanaman sebagai pakan. Soetrisno (2002) menjelaskan bahwa di daerah tropik unsur $\mathrm{N}$ adalah unsur yang pertama terendah disusul $\mathrm{P}$ dan $\mathrm{S}$, sedangkan yang mudah tercuci adalah $\mathrm{Ca}, \mathrm{Mg}, \mathrm{K}$, dan S. Kebanyakan tanah terutama yang diperuntukkan bagi kebun pakan yang dieksploitasi berlebihan menyebabkan kemunduran kandungan unsur hara karena tingkat serapan nitrogen yang tinggi untuk membentuk bagian vegetatif tanaman dan kurangnya bahan organik dari tanaman itu yang kembali menjadi $\mathrm{N}$ tanah. Kekurangan unsur $\mathrm{N}$ akan menyebabkan pertumbuhan tanaman terhambat yang berdampak pada penampakannya yang kerdil, daun-daun tanaman berwarna kuning pucat, dan kualitas hasilnya rendah. Dengan demikian pemberian N tambahan seperti urea sangat diperlukan, karena peningkatan penyerapan unsur $\mathrm{N}$ menunjukkan hal yang sejalan dengan produksi BK dan $\mathrm{BO}$ hijauan rumput (Yoku, 2010). Dwidjoseputra (1985) sebaliknya menjelaskan bahwa $\mathrm{N}$ yang terlampau tinggi menyebabkan batang tanaman lemah, tanaman mudah rebah karena sistem perakaran relatif menjadi lebih sempit. Berdasarkan uraian di atas, penentuan dosis urea yang tepat sangat diperlukan untuk menghasilkan produksi tanaman sorgum yang tinggi sebagai pakan ternak ruminansia.

Penelitian tentang pengaruh berbagai umur panen dan dosis urea terhadap produksi sorgum sebagai pakan ruminansia perlu dilakukan karena informasi mengenai produksi sorgum sebagai pakan ternak ruminansia pada berbagai umur panen dan dosis urea belum tersedia. Penelitian ini bertujuan untuk mengevaluasi kemampuan produksi BK, BO, dan PK tanaman sorgum varietas lokal Rote sebagai pakan ternak pada umur panen dan dosis urea yang berbeda.

\section{Materi dan Metode}

\section{Lokasi dan waktu}

Penelitian ini dilaksanakan di rumah kaca Laboratorium Hijauan Makanan Ternak dan Pastura Fakultas Peternakan UGM selama 4 bulan terhitung 
dari tanggal 11 November 2011 sampai 27 Februari 2012.

\section{Bahan penelitian}

Bahan yang digunakan adalah biji sorgum varietas lokal Rote, tanah, pupuk SP $36\left(36 \% \mathrm{P}_{2} \mathrm{O}_{5}\right)$, dan $\mathrm{KCl}\left(60 \% \mathrm{~K}_{2} \mathrm{O}\right)$, dan urea $(45 \% \mathrm{~N})$, polibag berukuran $18 \times 23 \mathrm{~cm}$ dengan diameter $22 \mathrm{~cm}$, kantong plastik, dan amplop besar.

\section{Peralatan penelitian}

Peralatan yang digunakan adalah timbangan digital berkapasitas $200 \mathrm{~g}$ dengan skala terkecil 0,01 $\mathrm{g}$ untuk menimbang pupuk, dan timbangan pegas berkapasitas $5 \mathrm{~kg}$ dengan kepekaan $0,5 \mathrm{~g}$ untuk menimbang hijauan, oven pengering, seperangkat peralatan untuk analisis kadar PK (Kjeldahl), dan tanur untuk uji kadar abu dan kadar BO.

\section{Prosedur penelitian}

Penelitian menggunakan metode eksperimen yang dirancang dengan Rancangan Acak Lengkap (RAL) pola faktorial dengan 2 faktor perlakuan dan 4 ulangan yaitu: faktor umur panen (UP) yang terdiri atas UP1 $=50$ hari, UP2 $=70$ hari, dan UP3 $=90$ hari, dan faktor kedua adalah dosis pemupukan urea $(\mathrm{P})$ yaitu $\mathrm{P} 0=$ tanpa urea, $\mathrm{P} 1=$ pupuk urea 50 $\mathrm{kg} / \mathrm{ha}$, dan $\mathrm{P} 2=$ pupuk urea $100 \mathrm{~kg} / \mathrm{ha}$, jadi dengan demikian terdapat $3 \times 3 \times 4=36$ satuan percobaan dalam 36 polibag.

Persiapan tanah meliputi: pembongkaran dan penghancuran tanah, kemudian dimasukkan ke dalam polibag sebanyak $10 \mathrm{~kg} /$ polibag. Polibag ditempatkan dengan jarak $0,5 \times 0,5 \mathrm{~m}$. Penentuan perlakuan pada polibag dilakukan secara acak berdasarkan pola RAL. Benih sorgum dipilih dari biji yang memenuhi syarat bibit yang baik. Penanaman dilakukan dengan membuat lubang tanam dalam polibag. Dalam 1 lubang tanam diisi 4 biji sorgum, kemudian ditutup kembali.

Pemberian pupuk SP $36\left(36 \% \mathrm{P}_{2} \mathrm{O}_{5}\right)$ dengan dosis $75 \mathrm{~kg} /$ ha dilakukan sekaligus pada saat tanam dan pupuk $\mathrm{KCl}\left(60 \% \mathrm{~K}_{2} \mathrm{O}\right)$ sebanyak $75 \mathrm{~kg} / \mathrm{ha}$ diberikan sebanyak 2 kali yaitu 37,5 kg/ha diberikan saat penjarangan tanaman dan sisanya diberikan saat tanaman berumur satu bulan. Pupuk urea diberikan pada saat tanaman berumur 10 hari sesuai dengan perlakuan. Pupuk-pupuk ini diberikan dengan cara dibenamkan dengan jarak $+5 \mathrm{~cm}$ dari lubang tanam. Penjarangan tanaman dilakukan saat tanaman berumur 10 hari dengan hanya meninggalkan 2 tanaman terbaik di setiap lubang tanamnya. Penyiraman tanaman dilakukan setiap hari hingga mencapai kapasitas lapang. Penyiangan tanaman dilakukan jika ada gulma. Hama ditanggulangi dengan penyemprotan insektisida merek Dursban.
Pada saat panen dilakukan pengukuran terhadap produksi hijauannya. Pemotongan tanaman dilakukan pada batang dengan jarak $\pm 5 \mathrm{~cm}$ dari atas tanah. Hijauan yang diperoleh dimasukkan dalam kantong koran yang telah diketahui beratnya kemudian dikeringkan dalam oven dengan suhu $55^{\circ} \mathrm{C}$ selama 3 hari hingga mencapai berat konstan. Sampel hijauan tersebut digiling dengan diameter lubang saringan $1 \mathrm{~mm}$ dan selanjutnya dilakukan analisis BK, BO, dan PK (AOAC, 2005).

\section{Variabel yang diamati}

Variabel yang diamati antara lain produksi BK tanaman bagian atas, produksi PK, dan BO. Produksi tanaman bagian atas terdiri atas daun, batang, dan buah. Produksi BK tanaman diperoleh dari persentase BK dikalikan dengan berat kering tanaman (g/polibag). Produksi PK diperoleh dari persentase PK dikalikan dengan berat kering tanaman (g/polibag). Produksi BO diperoleh dari persentase BO dikalikan dengan berat kering tanaman (g/polibag).

\section{Analisis data}

Data yang diperoleh, dianalisis variansi menurut RAL pola faktorial. Uji Duncan (Duncan's New Multiple Range Test) dilakukan pada faktor perlakuan untuk menunjukkan pengaruh yang signifikan (Gomez dan Gomez, 2010).

\section{Hasil dan Pembahasan}

\section{Produksi BK tanaman sorgum}

Tabel rerata produksi BK tanaman sorgum dengan perlakuan faktor umur panen, faktor dosis pemupukan urea, dan interaksi antara kedua faktor tersebut memberikan pengaruh yang sangat nyata $(\mathrm{P} \leq 0,01)$. Pada faktor umur panen, produksi $\mathrm{BK}$ tanaman bagian atas semakin meningkat dengan bertambahnya umur pemotongan. Produksi BK tertinggi terdapat pada perlakuan UP3 yang diikuti dan berbeda dengan UP2 dan UP1. Hal ini disebabkan karena makin banyaknya waktu yang tersedia bagi tanaman untuk berfotosintesis maka semakin banyak terjadi akumulasi hasil fotosintesis di dalam jaringan tanaman. Hal ini sesuai dengan pendapat Gardner et al. (2008) bahwa makin lama terjadinya asimilasi, makin tinggi berat kering tanaman. Pada faktor dosis pemupukan urea, produksi BK tanaman sorgum tertinggi pada perlakuan $\mathrm{P} 2$ diikuti dan berbeda dengan $\mathrm{P} 1$, dan yang terendah pada perlakuan P0. Hal tersebut disebabkan oleh semakin banyaknya dosis pemupukan urea maka akan semakin banyak pula $\mathrm{N}$ yang tersedia yang akan memaksimalkan proses fotosintesis dan meningkatkan akumulasi hasil fotosintesis pada bagian tanaman bagian atas. Hal 
ini sesuai dengan pendapat Gardner et al. (2008) bahwa proses fotosintesis sangat dipengaruhi oleh daya kerja peralatan fotosintesis termasuk klorofil. Klorofil mengandung $\mathrm{N}$, dengan demikian makin banyak $\mathrm{N}$ yang tersedia, makin tinggi hasil fotosintesisnya. Pada interaksi kedua faktor, produksi BK tertinggi terdapat pada perlakuan UP3P2 yang berbeda sangat nyata $(P \leq 0,01)$ dengan UP3P1, UP3P0, UP2P2, dan UP2P1, serta UP2P0. Produksi BK terendah terdapat pada UP1P2, UP1P1, dan UP1P0. Hal ini terjadi karena kombinasi antara N tersedia cukup banyak dengan lama waktu yang cukup untuk berfotosintesis dan menyimpan hasil fotosintesis dalam tubuh tanaman. Produksi BK yang tinggi pada UP3P2 ini juga didukung oleh berat akar yang juga tertinggi pada perlakuan tersebut. Berat akar yang tinggi tersebut menggambarkan tingginya aktivitas akar dalam proses penghantaran nutrien untuk fotosintesis yang juga tinggi. Hal ini sesuai dengan pendapat Balabanli et al. (2010) bahwa pemupukan $\mathrm{N}$ akan meningkatkan produksi BK tanaman pakan. Penambahan pupuk N pada lahan bagi tanaman pakan merupakan metode yang paling efisien untuk meningkatkan produksi BK tanaman pakan yang ada.

Rerata produksi BK bagian atas dari tanaman sorgum pada penelitian ini adalah 58,56 g/polibag. Produksi BK ini lebih rendah dari produksi BK rumput gajah yaitu $120 \mathrm{~g}$ sebagaimana yang dilaporkan oleh Sinaga (2005).

\section{Produksi PK tanaman sorgum}

Hasil uji statistik pada menunjukkan bahwa faktor dosis pemupukan urea memberikan pengaruh yang sangat nyata $(\mathrm{P} \leq 0,01)$ terhadap produksi $\mathrm{PK}$ hijauan sorgum (Tabel), akan tetapi faktor umur panen tidak berpengaruh nyata. Interaksi antara faktor umur panen dan dosis pemupukan urea memberikan pengaruh yang nyata $(\mathrm{P} \leq 0,05)$ terhadap produksi PK hijauan sorgum.

Pada faktor dosis pemupukan urea, produksi PK hijauan sorgum tertinggi pada perlakuan P2 diikuti dan berbeda dengan P1, yang juga berbeda dengan P0 yang menghasilkan produksi PK terendah. Hal tersebut disebabkan oleh semakin banyaknya dosis pemupukan urea maka akan semakin banyak pula $\mathrm{N}$ yang tersedia sebagai bahan baku pembentukan protein.

Pandutama et al. (2003) menjelaskan bahwa produk akhir dari urea adalah dalam bentuk ion $\mathrm{NH}_{4}^{+}$dan $\mathrm{NO}_{3}^{-}$untuk diserap tanaman. Hasil analisis $\mathrm{N}$ tersedia di dalam tanah menunjukkan bahwa $\mathrm{N}$ tersedia pada $\mathrm{P} 0$ adalah $222,42 \mathrm{ppm}$, pada P1 menjadi 286,08 ppm dan meningkat menjadi 349,92 ppm pada P2. Makin banyak N tersedia bagi tanaman maka semakin tinggi pula produksi protein sorgum.

Kondisi ini didukung pula oleh produksi BK yang juga tinggi pada perlakuan P0. Hasil interaksi kedua faktor perlakuan, menyebabkan produksi PK tertinggi terdapat pada perlakuan UP2P2 yang tidak

Tabel rerata produksi bahan kering, bahan organik, dan protein kasar hijauan sorgum (g/polibag) (average of dry matter, organic matter and crude protein production of sorghum forage (g/polybag))

\begin{tabular}{|c|c|c|c|}
\hline $\begin{array}{l}\text { Perlakuan } \\
\text { (treatment) }\end{array}$ & $\begin{array}{l}\text { Produksi bahan kering } \\
\text { (dry matter production) }\end{array}$ & $\begin{array}{c}\text { Produksi bahan organik } \\
\text { (organic matter production) }\end{array}$ & $\begin{array}{c}\text { Produksi protein kasar } \\
\text { (crude protein production) }\end{array}$ \\
\hline UP1P0 & $25,34^{\mathrm{e}}$ & $25,60^{\mathrm{e}}$ & $02,96^{\mathrm{c}}$ \\
\hline UP1P1 & $29,15^{\mathrm{e}}$ & $28,70^{\mathrm{e}}$ & $03,35^{\mathrm{b}}$ \\
\hline UP1P2 & $33,86^{\mathrm{e}}$ & $32,88^{\mathrm{e}}$ & $05,03^{\mathrm{a}}$ \\
\hline UP2P0 & $48,24^{\mathrm{d}}$ & $47,23^{\mathrm{d}}$ & $02,75^{\mathrm{cd}}$ \\
\hline UP2P1 & $61,83^{\mathrm{c}}$ & $60,46^{\mathrm{c}}$ & $03,83^{\mathrm{b}}$ \\
\hline UP2P2 & $68,89^{\mathrm{c}}$ & $70,98^{\mathrm{c}}$ & $05,57^{\mathrm{a}}$ \\
\hline UP3P0 & $68,61^{\mathrm{c}}$ & $69,21^{\mathrm{c}}$ & $02,22^{\mathrm{d}}$ \\
\hline UP3P1 & $83,86^{\mathrm{b}}$ & $84,70^{\mathrm{b}}$ & $03,71^{\mathrm{b}}$ \\
\hline UP3P2 & $107,27^{\mathrm{a}}$ & $108,07^{\mathrm{a}}$ & $05,14^{\mathrm{a}}$ \\
\hline \multicolumn{4}{|l|}{ Summary } \\
\hline \multicolumn{4}{|l|}{ Umur panen } \\
\hline UP1 & $29,45^{\mathrm{h}}$ & $29,06^{\mathrm{h}}$ & $03,78^{\mathrm{ns}}$ \\
\hline UP2 & $59,65^{\mathrm{g}}$ & $59,55^{\mathrm{g}}$ & $04,05^{\mathrm{ns}}$ \\
\hline UP3 & $86,58^{\mathrm{f}}$ & $87,33^{\mathrm{f}}$ & $03,69^{\text {ns }}$ \\
\hline \multicolumn{4}{|l|}{ Dosis urea } \\
\hline P0 & $47,40^{\mathrm{k}}$ & $47,34^{\mathrm{k}}$ & $02,64^{\mathrm{k}}$ \\
\hline P1 & $58,28^{j}$ & $57,95^{\mathrm{j}}$ & $03,63^{j}$ \\
\hline P2 & $70,01^{\mathrm{i}}$ & $70,64^{\mathrm{i}}$ & $05,25^{\mathrm{i}}$ \\
\hline
\end{tabular}


berbeda dengan UP3P2 dan UP1P2, dan berbeda dengan UP3P1, UP2P1 dan UP1P1. Produksi PK dari kombinasi perlakuan yang telah disebutkan tadi, juga berbeda dengan UP1P0 dan UP2P0. Perlakuan UP3P0 merupakan kombinasi perlakuan yang menghasilkan produksi PK terendah. Walaupun demikian produksi PK pada UP3P0 tidak berbeda dengan UP2P0. Hal ini merupakan hasil kombinasi antara $\mathrm{N}$ yang cukup tersedia dengan tingginya akumulasi hasil fotosintesis dalam jaringan tanaman. Produksi PK yang tinggi juga didukung oleh produksi berat kering yang juga tinggi pada perlakuan tersebut. Balabanli et al. (2010) menyatakan bahwa produksi PK tanaman pakan sangat tergantung pada produksi BK tanaman dan kadar PK tanaman tersebut. Lebih lanjut dijelaskan bahwa penambahan pupuk $\mathrm{N}$ akan meningkatkan produktivitas tanaman dan kadar PK tanaman pakan. Rerata produksi PK hijauan sorgum pada penelitian ini adalah $3,84 \mathrm{~g} /$ polibag.

\section{Produksi BO tanaman sorgum akibat perlakuan}

Data pada Tabel menunjukkan bahwa faktor umur panen dan dosis pemupukan urea dan interaksi antara kedua faktor ini memberikan pengaruh yang sangat nyata $(\mathrm{P} \leq 0,01)$ terhadap produksi $\mathrm{BO}$ serta terdapat interaksi yang sangat nyata antara kedua faktor tersebut. Produksi BO hijauan sorgum semakin meningkat dengan meningkatnya umur panen. Pada UP2, peningkatan produksi BO hampir 2 kali lipat dari UP1 dan pada UP3, produksi BO meningkat 3 kali lipat dari UP1. Pengaruh dosis pemupukan urea terhadap produksi BO hijauan sorgum tertinggi pada perlakuan P2 diikuti dan berbeda dengan P1. Produksi BO terendah terjadi pada perlakuan P0. Pengaruh interaksi kedua faktor, produksi BO tertinggi terdapat pada perlakuan UP3P2 yang diikuti dengan UP3P1, selanjutnya diikuti dan berbeda dengan UP3P0, UP2P2, UP2P1, dan UP2P0. Produksi BO terendah terdapat pada kombinasi perlakuan UP1P0 yang ternyata tidak berbeda dengan UP1P2 dan UP1P1. Data menunjukkan bahwa pada UP1, dosis pupuk urea belum memberikan pengaruh yang nyata pada produksi $\mathrm{BO}$, begitu pula pada umur panen UP2. Perlakuan UP3, mulai memperlihatkan bahwa jumlah nitrogen ternyata mempengaruhi produksi BO. Tanaman sorgum pada UP3 yang tidak dipupuk dengan urea, menghasilkan jumlah bahan organik yang tidak berbeda dengan UP2. Data ini mengindikasikan bahwa dengan dosis pemupukan urea $100 \mathrm{~kg} / \mathrm{ha}$ bagi tanaman sorgum dan lama hidup 90 hari, tanaman sorgum akan mengakumulasikan $\mathrm{BO}$ hasil fotosintesisnya dan jumlah paling maksimal. Produksi BO yang tinggi pada UP3P2 ini juga didukung oleh produksi BK dan PK, dan kadar BO hijauan sorgum yang juga tinggi pada perlakuan tersebut. Salisbury dan Ross (1995) menjelaskan bahwa komponen utama dalam berat kering tanaman adalah senyawa polisakarida dan lignin pada dinding sel, ditambah komponen sitoplasma seperti protein, lipid, asam amino dan asam organik. Hal ini sesuai dengan pendapat Yoku et al. (2007) bahwa Sorghum sudanense (rumput sudan) sebagai tanaman pakan yang dipupuk $\mathrm{N}$ akan menghasilkan produksi $60 \%$ lebih banyak daripada yang tidak dipupuk. Produksi BO yang tinggi ini juga merupakan ekspresi dari laju pertumbuhan yang tinggi. Rerata produksi $\mathrm{BO}$ hijauan sorgum pada penelitian ini adalah 58,65 g/polibag.

\section{Kesimpulan}

Tanaman sorgum varietas lokal Rote yang dipanen pada umur 90 hari dengan dosis pupuk urea $100 \mathrm{~kg} / \mathrm{ha}$, memproduksi BK, BO, dan PK tertinggi. Disarankan bahwa umur panen yang tepat bagi sorgum sebagai pakan ternak adalah 90 hari dengan dosis pupuk urea $100 \mathrm{~kg} / \mathrm{ha}$.

\section{Ucapan Terima Kasih}

Ucapan terima kasih disampaikan kepada DIKTI yang telah memberikan beasiswa program pasca sarjana (BPPS - S3) dan telah membiayai penelitian ini.

\section{Daftar Pustaka}

AOAC. 2005. Official Methods of Analysis of the Association of Official Analytical Chemists. Association of Official Analytical Chemists Publ. Maryland.

Balabanli, C., S. Albayrak and O. Yuksel. 2010. Effects of nitrogen, phosphorus and potassium fertilization on the quality and yield of native rangeland. Turkish Journal of Field Crops 15(2): 164-168.

Budiman, R.D. Soetrisno, S.P.S. Budhi and A. Indrianto. 2011. Total non structural carbohydrate (TNC) of three cultivar of napier grass (Pennisetum purpureum Schum) at vegetative and generative phase. Journal of The Indonesian Tropical Animal Agriculture, 36 (2): 126-130.

Dwidjoseputra, D. 1985. Pengantar Fisiologi Tumbuhan. PT Gramedia. Jakarta.

Gardner, F.P., R.B. Pearce, dan R.L. Mitchell. 2008. Fisiologi Tanaman Budidaya. Terjemahan. UI Press. Jakarta. 
Gomez, K.A. dan A.A. Gomez. 2010. Prosedur Statistik untuk Penelitian Pertanian. Terjemahan Edisi Kedua. UI Press. Jakarta.

Huston, J.E. and W.E. Pinchak. 2008. Range Animal Nutrition. In: Grazing management a; An Ecological Perspective. Available at http://cnrit.tamu.edu/riem/textbook/Chapter2. $\mathrm{htm}$. Accession date: 15 September 2012.

Mc Donald, P., R.A. Edwards, and J.F.D. Greenhalgh. 2002. Animal Nutrition. Sixth Edition. Pearson Prentice Hall.

OISAT. 2011. Sorghum. PAN Germany Pestizid Aktions-Netzwerk e.V. PAN Germany.

Pandutama, M.H., A. Mudjiharyati, Suyono, dan Wustamidin. 2003. Dasar-Dasar Ilmu Tanah. Jurusan Tanah Fakultas Pertanian Universitas Jember.

Salisbury, F.B. and C.W. Ross. 1995. Fisiologi Tumbuhan - Jilid 3. Terjemahan. Penerbit ITB. Bandung.
Sinaga, R. 2005. Tanggap morfologi, anatomi dan fisiologi rumput gajah dan rumput raja akibat penurunan ketersediaan air. Tesis. Sekolah Pascasarjana. Institut Pertanian Bogor.

Soetrisno, R.D. 2002. Potensi tanaman pakan untuk pengembangan ternak ruminansia. Pidato Pengukuhan Jabatan Guru Besar pada Fakultas Peternakan. Universitas Gadjah Mada. Yogyakarta.

Yoku, O., D. Soetrisno, R. Utomo, dan S.A. Siradz. 2007. Pengaruh perlakuan jarak tanam dan pemupukan NPK terhadap produksi rumput sudan (Sorghum sudanense). Jurnal Agritek 15: 81-87.

Yoku, O. 2010. Produksi hijauan dan nilai nutrisi wafer rumput sudan (Sorghum sudanense) sebagai pakan ternak ruminansia. Disertasi. Program Pascasajana Universitas Gadjah Mada. Yogyakarta. 